\title{
Teaching Children to Save in Early Childhood
}

\author{
Daviq Chairilsyah $\bowtie$ \\ Pendidikan Guru Pendidikan Anak Usia Dini, Universitas Riau \\ DOI: $\underline{10.31004 / o b s e s i . v 5 i 2.1077}$
}

\begin{abstract}
Abstrak
Anak terkadang hidup boros karena orang tua terlalu banyak memberi uang dan barang sehingga membuat anak tidak berpikir dewasa dan kurang menghargai nilai uang dan barang tersebut. Artikel ini bertujuan untuk meningkatkan peran orang tua dalam mendidik anak sejak dini untuk mengenalkan anak tentang mengelola keuangan secara bijaksana dan cerdas yaitu dengan cara menabung dan berhemat. Penelitian menggunakan metode literatur reviu. Hasil penelitian ini adalah pentingnya mengedukasi anak tentang nilai uang, menjelaskan nilai menabung, memberikan saran tentang manfaat menabung untuk masa depan dan melakukan praktek langsung menabung melalui celengan.
\end{abstract}

Kata Kunci: menabung; mengajarkan; anak usia dini.

\begin{abstract}
Children sometimes live extravagantly because their parents give too much money and goods so that children not appreciate the value of money and goods. This article purpose to increase the roles of parents are urgently needed in educating children from the start to introduce children to managing finances wisely and intelligently. A literature review is used in this research. The result are to educate children about the value of money, explain the value of saving in the future, give suggestions about the benefits of saving, and give the piggy bank an interesting shape.
\end{abstract}

Keywords: save; teaching; early childhood.

Copyright (c) 2021 Daviq Chairilsyah

$\square$ Corresponding author:

Email Address: daviqch@yahoo.com (Pekanbaru, Riau, Indonesia)

Received 5 November 2020, Accepted 27 December 2020, Published 8 March 2021

\section{INTRODUCTION}

Saving is an activity to fulfill a need, namely material security. Saving requires a desire in a person to set aside and save money in the bank or at home. Saving requires interest so that its behavior is directed towards that activity (saving). A saving activity can also be done at school, usually coordinated by the classroom teacher. Each student can set aside the remaining pocket money to save. There are many benefits to saving at school. Students can take their savings at any time if needed. Students can also withdraw their savings at the end of the year for activities at school (Laili, 2015). The safest savings can be done at a bank, both state-owned and private-owned banks. Depositing and withdrawing money from the bank is also very easy. We only need to come to the bank with a passbook, then fill out a deposit or withdrawal form. Usually, to attract customers to save at the bank, the bank provides various kinds of raffles with attractive prizes (Ludianan dkk, 2019). 
Today, saving is an important thing to be taught to children. Some parents have started to instill this behavior in their children from a very young age because they believe it will help their children in the future (Imelda, 2017). Saving means setting aside some of the money we have to save separately and it is one way to manage money or finances. It's easiest to save at home because you can do it all the time. However, saving at home is no guarantee of security. Sometimes we are easily tempted to take money in savings little by little for momentary needs so that in the end the money we save ends up running out (Mustari, 2014).

There are many benefits that we can get if we set aside some of our money for savings, reflecting on the wise words "rajin pangkal pandai, hemat pangkal kaya" which means be diligent at the base of the clever, save for the base of the rich). We should begin to instill these words of wisdom in children from an early age and teach them to live frugally by saving money so that useless consumptive patterns can be reduced. The benefits of saving can be obtained when we do it regularly and diligently. It aims to carry out a thrifty lifestyle and is also a characteristic development of not wasting money that has been highly applied since an early age (Ministry of Education and Culture, 2016; Soviah, 2019).

Saving is an activity to save part of the income for urgent and sudden needs for the future. It means setting aside some of the money you have for a certain period. Saving is an activity that we should bear in mind because this activity is necessary and must be started at an early age. Saving is a positive activity because it allows children to become more economically independent and enable parents to learn financial coaching (Mundir, 2018).

Teaching children to save from an early age is beneficial for character building (Indonesia, 2018). Generally, the world community is changing rapidly and dynamically and needs competent resources. By saving, it means that we facilitate the development of all aspects of children's intelligence. Many believe it is not good to introduce money to children because it is feared that children will become consumptive. Introducing children to money early on invites them to appreciate money. Besides, they also simultaneously learn to count from the nominal (Marlina, 2019).

Saving will get used to living frugally because expenses are adjusted to the needs and meet other needs in the future. Besides, teaching saving from an early age has benefits, namely that children are accustomed to learning to manage personal money, have financial planning, respect money, learn discipline, and create pride.

An easy way, teach kids to save is by giving them targets and comparisons. Suppose they want to buy something they want, then they have to save for a certain period. If an item is expensive, then the child has to save more to get it. Then to instill the behavior of saving from early childhood, namely by using a piggy bank, for coins and banknotes. Meanwhile, other media that can be used in this socialization activity are whiteboards, markers, stickers, children's names, and piggy banks for children.

Saving is saving a certain amount of money so that it can be used at a later date if needed. The scientific definition is that savings are deposits from third parties whose withdrawals according to certain agreed terms, but cannot be withdrawn by check, billyet giro, and other similar means (Setiawati, 2015; Christian, 2018). Besides, savings are also often defined as the income of a society that is not spent and is only stored as a reserve to be used as a precaution for a short period.

According to Haryono (2020), saving has the following objectives, namely: a) saving expenses so that life is not wasteful, b) managing finances properly, c) planning and preparing for the future, d) making development a success.

Meanwhile, the benefits of saving are as follows: a) meeting urgent needs, b) meeting the costs of various needs, and c) meeting future needs (Haryono, 2020). Having a habit of saving is very useful for our future. The more money you save, the better. There is a saying that says "save the base of the rich", this means that if we are diligent in saving a lot of money and living a simple life is not excessive, then in the end we will be able to enjoy happy results. 
Getting used to saving from childhood will be able to form a thrifty character, think ahead, not be selfish, patient, and so on. For that, if we have children, then educate our children so that they become great savers. But avoid excessive frugality or worry about negative perceptions of future needs so that we don't become stingy or miserly.

Teaching children to save behavior is certainly not done instantly. According to Nurjanah (2018) there are several stages in teaching children to save, such as, a) explain first the meaning of saving from an early age to children. b) Give a gift in the form of a piggy bank with the child's name on it. c) Encourage children to immediately put money in the piggy bank. d) Praise the children for putting money in their piggy bank. e) Discuss with the children about the money in the piggy bank when the piggy bank is full. f) Guide children that if the piggy bank is full, the children can use it and the change from the purchase of the desired item can be saved again.

\section{METHODOLOGY}

Literature studies can be applied to have a better or depth understanding of research objectives. Researchers will not only know things about the object of research more broadly but also conducting a literature study that can also make conclusions from the results of previous researchers' writings. Therefore, researchers can make updates in their research so that they have different final findings from previous related studies.

Sources that can be used as material for a literature study should not be arbitrary. Not all research papers or studies can be taken as a reference. Some that are common and suitable for use are books by trusted authors, accredited scientific journals, and student research results in various forms such as theses, theses, dissertations, and practicum reports. Several methods can be implemented to conduct a literature study, such as criticizing, comparing, summarizing, and synthesizing literature (Sugiyono, 2015).

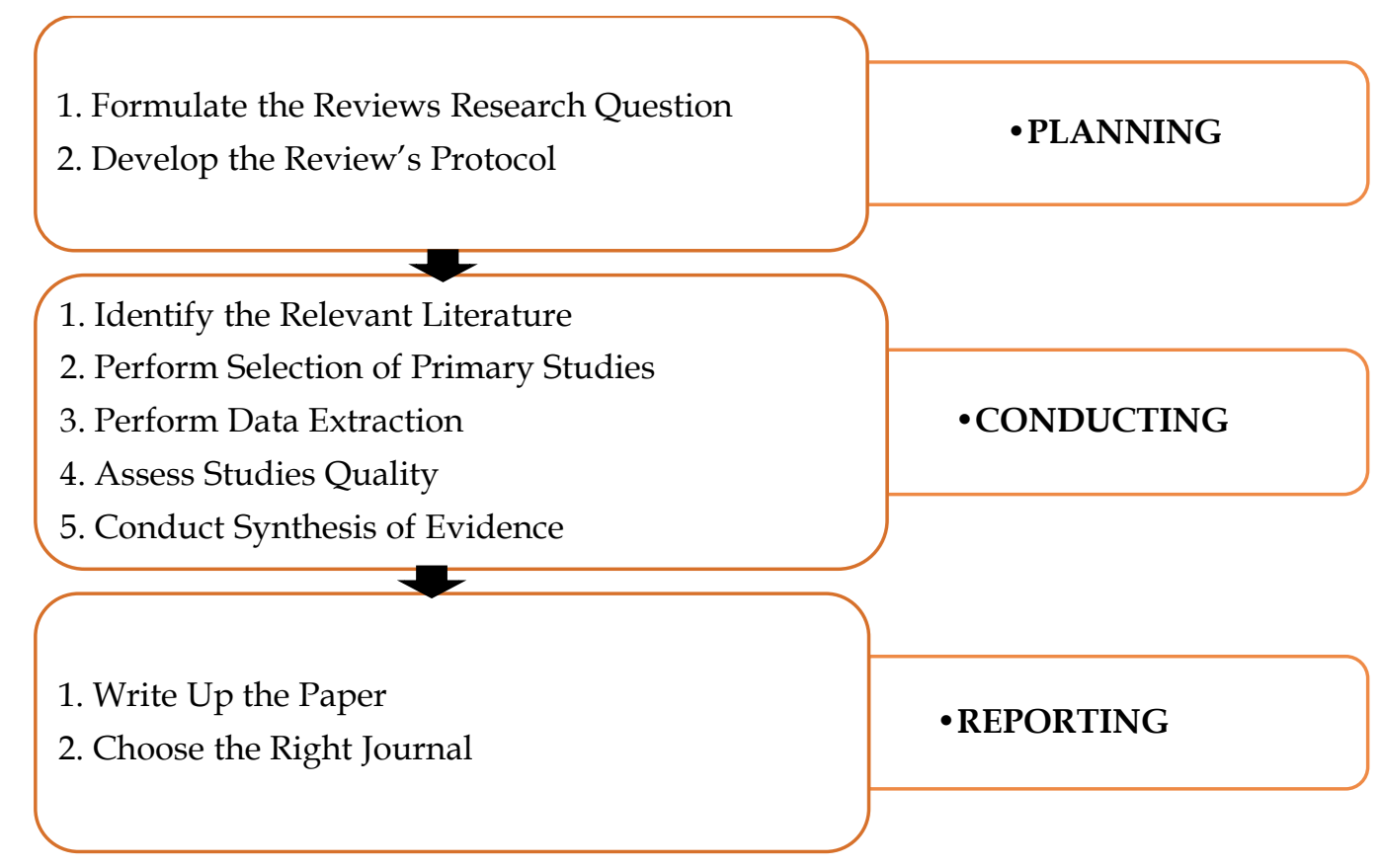

Picture 1. Steps Literature Study

A literature study is one technique that can be used in carrying out a study. A literature study is a way to solve problems by tracing the sources of writing that have been made before. In other words, the term literature study is also very familiar with the term literature review. In research that is to be carried out, of course, a researcher must have a broad insight into the object to be studied. If not, then it is certain in a large percentage that the research will fail. 
In this literature review study, the author tries to provide an understanding of the importance of this saving behavior which can have a positive effect on early childhood development. Besides, researchers also try to provide opinions and suggestions for teachers and parents in educating children so that children want to value money, live frugally, and save for their future.

\section{RESULT AND DISCUSSION}

Parents are both teachers and facilitators to guide and facilitate their children towards the future. Then how do children save and how do parents facilitate this? Parents must be honest and transparent. Of course this attitude is based on love and love for children. Parents don't just give pocket money every day to their children, but try to communicate it by offering their children where to buy snacks and which to save. Every month or every six months, children who are savers must know and be shown to him that the amount of their savings until this month is already so high (Aziz, 2015). This was explained honestly and transparently, so that the children really believed. If the child has entered school (SD, SMP or SMA) this pattern of behavior continues and continues saving activities at the bank.

Children are sometimes lazy to save, especially if the place where they save their money is less attractive. Parents should be more sensitive to this issue. Sometimes parents are just ignorant of the attitude of their children who want to save money. Some parents do not just say to their children "here, son, you save money in the mother's cupboard so that the money is safe" . To be even more effective, parents must buy savings media for children so that the child can be more active in saving, such as buying a piggy bank that looks like an animal, or cartoon characters that the children admire (Pulungan dkk, 2019).

\section{Tips for Teaching Children to Save Early}

Teaching saving behavior in early childhood is certainly not an easy thing, and it needs a long process. Here are some tips for teaching children to save early such as teaching children to save from their own time is an effective way to make children grow up as planning people, including in financial matters (Hewi \& Asnawati, 2020). Many have proven that successful people are those who know how to manage their money properly, namely how to save and spend money properly. Teaching children to save from an early age is very important because we can teach how valuable money is and it is not good to waste it. Explain the importance of saving. Teaching children to save from an early age can be started by explaining to children about saving and its benefits first. Give an example of your experience when saving so that children understand and see concrete evidence of the benefits of saving. Also, explain the differences in needs and desires so that children are far from wasteful habits.

Create a special bank account for children. Providing a container for savings to children can be started by buying them a piggy bank. Have the child fill the piggy bank regularly. After being old enough, you can make an account for your child. When creating an account, take your child so that the child knows that the account belongs to him. These savings will give them hope to have their own money one day, and start saving early. After the account is opened, encourage children to be disciplined in filling their savings regularly. Teach children to set aside pocket money. After you have a personal bank account or piggy bank at home, make it a habit for your child to set aside some of the pocket money or other money he receives, for example, gifts from grandparents or uncles or gifts every time your child does homework or helps you do household chores. Do not let the money be saved intentionally given by you. For example, always ask your child to set aside $10 \%$ of the total allowance you give each week. Activities like this stimulate children to save automatically when they get used to it.

Make a grocery list specifically for children. When shopping monthly, you don't have to leave your children at home. Your child can come, provided he has his grocery list. The child's grocery list should be discussed with you so that your child will know what needs and what wants. That way, your child will know which ones are the priority. When shopping tries 
not to stray from the list. Unconsciously, your child will gradually get used to prioritizing designing a list of their needs every month. Turn off household appliances when not in use. Frugality does not always have to be related to money but also related to how we maintain the house appliances. Apply this to your children so that they get used to valuing things. If their belongings are taken care of, then do not have to buy a new one. Some examples are, turning off the computer when not in use, turning off the lights when leaving the room. Let your child get used to this habit so that in the future he can save more.

Buy items according to primary needs. Never teach children to be extravagant. Parents usually don't know the boundaries between this and loving children. Loving children means preparing children for their future lives, while waste is buying a lot of things as long as the child is happy without knowing the consequences in the future. Make a target. Ask the children to choose a target that will be completed with the saving. For example, to spend on vacation or buy toys that the child wants. Teach children to save to fulfill their desires and the rest is saved as a reserve. Set a good example. Children will not adopt the habit of saving if they often see their parents wasting money. Set an example and show what good savings habits are.

A person who is smart in managing money cannot be formed in just one day. They learn from years of experience coupled with parental guidance from childhood. Do not let children fall asleep with a comfortable life even though you earn very much more. Giving too many things makes children not think mature and even less appreciative of these items. Prioritize items for primary needs, such as school supplies and others. Give non-primary items at certain times, such as birthdays or going to class (Sumiyati, 2017).

Today's children still do not understand productivity-value, and it is easy to spend their parents' money. Children sometimes live extravagantly because their parents earn more. They are not oriented that investing or saving will be very profitable in the future, especially to meet education needs. The role of parents is important in educating children from the start to introduce children to managing finances wisely and intelligently, namely by saving money or what can be called saving money and thrift (that way children will better understand that they will appreciate being thrifty in their life).

\section{Strategies for Children to Be Diligent in Saving}

Teaching children to be diligent savers of course must be done strategically. Some of the strategies that parents can do so that children are diligent in saving are, cultivate saving habits to yourself. First, start with yourself. If you like to do extravagant things like shopping and buying food outside of your needs, then your child will imitate your attitude indirectly. So, you have to get used to being frugal and like to save first. Ask children to save at school. If your child's school has a savings program, then you should ask him or her to participate. Besides this program will help you reduce future school fees, it will also provide interesting lessons for children about saving. So, make sure you bring your child savings with you when your child goes to school, and make sure you also check the school savings book to see if the child has given her savings, then show the child so that he can imitate it.

Limit their pocket money. You also need to limit your child's pocket money so that he doesn't often buy snacks and toys, at least you give pocket money equal to the nominal amount of pocket money of his friends, even though you are very capable of giving extra pocket money yourself. This is to train him not to buy snacks and toys often. Encourage your children to set aside money. Now, try to ask your child to set aside pocket money, both school allowance and daily allowance. Then, ask him to save the rest of the pocket money or put it in the piggy bank. Tell them the benefits. Next, often advise children about the benefits of saving. For example, you say that saving will help him in the future, saving is the key to success, and so on.

Motivate them. Children also need spiritual energy from you in this case, this energy can be in the form of motivations. For example, you tell stories of successful people from the results of saving, show motivational videos of the benefits of saving, and so on. It aims to make 
children more eager to save. Help them to make and reach the target. For example, if your child asks to buy him a new backpack, you shouldn't buy a new one for him right away. However, teach him how to be able to buy a new bag without the help of his parents, namely by setting aside money and saving money. Praise and hug when he starts saving. If your child can set aside pocket money and save, then show him how proud you are, praise him, kiss and hug him. This proud and loving attitude you give will motivate your child to keep going.

Give the present. As well as compliments, kisses, and hugs, it's also crucial to give your child a surprise gift if he or she gets used to saving. The goal is the same, to bring happiness to children and to generate motivation to continue saving. Occasionally Take Your Children to the Bank to Save Money. Finally, every time you go to the nearest bank branch, either to save money or to withdraw, take your child with you. Tell him about things related to banks and efforts to save so that children can imitate him.

\section{Teach Children to Save Money}

According to Marlina (2019) saving is basically based on the thriftiness of money that one person receives from other people. The following will explain how to teach children to save money, such as, educate them about the value of money. After the children learn and understand how to count, that is the right time to give money understanding. Parents should be consistent and simply explain to them so that they allow the child to remember (Sulistyowati, 2019). Explain the value of saving. Provide understanding so that they understand that saving has a positive impact. Setting aside pocket money can be useful and profitable when needed in an emergency, this benefit can be felt in the long run.

Give suggestions about the benefits of saving. As intelligent parents, they should give suggestions to children that saving is an anticipatory action to meet future education costs. Besides saving, it also trains children to be patient if they want something, for example, shoes, bags, books, it is even possible for secondary needs such as toys. Give the piggy bank an interesting shape. Psychologically, children will be interested in doing something to an object if it has a strong attraction in their eyes. We can take advantage of that by giving the child a piggy bank with a unique and cute shape. You can buy a piggy bank that looks like cartoon characters your child likes. It can also be a piggy bank in the shape of a cash machine that is sold in the market.

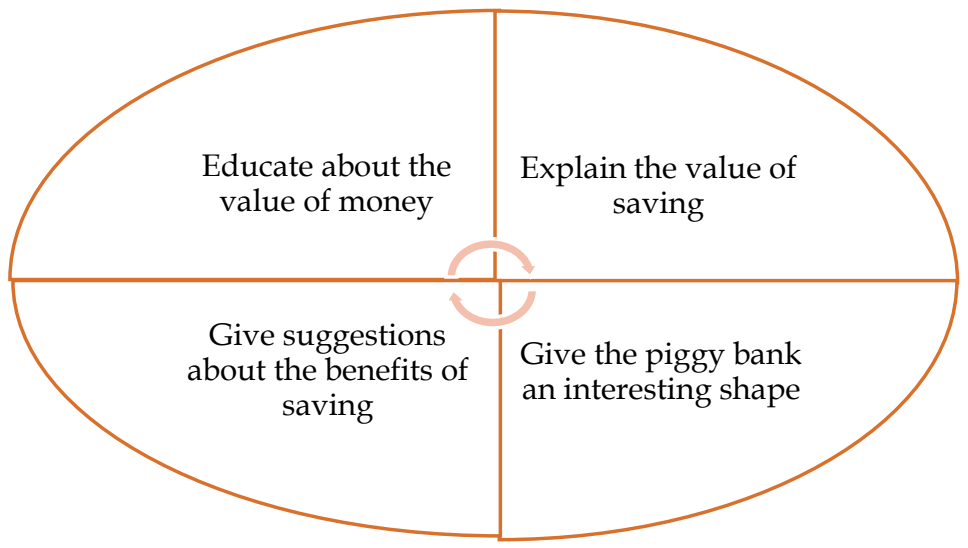

\section{Picture 2. Teaching children to save money}

Saving is an effective lesson in frugality, planning, and building the future as well. All parents want their children to be active in saving, by setting aside a portion of the cost of their daily snacks to save. In this case, the parents first should explain to their children that saving money or goods is for future needs (Ludiana, 2019). The savings are the result of our efforts for life in the future. Therefore, do not spend pocket money instead of saving as much as 
possible. This habit is a lesson for children to get used to living frugally and not wastefully. Furthermore, for parents, the savings card owned by the child can function as a control over how he or she regulates the pattern of daily snacks. That way there will be reciprocal communication between parents and children. This method is good for cultivating wise traits in children in terms of managing their finances.

Learning in terms of saving from an early age to children is not forced. But parents can communicate by giving explanations to their children about the meaning of saving. It is better if parents and children save together, and occasionally they play at the bank. In that place, the parents explain to their children that this is the place where our money is stored in the form of savings. In this place our money is safe and can be retrieved at any time. It seems that for an early age, parents must be active in providing good examples and attitudes in terms of sharing the snack pattern, for today and for saving in savings. Children at an early age do not have a concrete picture of the future. But through pictures of the lives of pious children, both in magazines and in newspapers can be introduced. It is also important for parents to avoid hedonic attitudes, because hedonic is a waste that makes parents and children lazy to save (Nurjanah, 2018).

Carving for the future must start at an early age. Parents are obliged to facilitate their children to achieve a bright future (Yenawati, 2018). The future depends on our attitude today. The future will be bright if children behave well, in the sense of living frugally, having plans, and not being wasteful. This circumstance must be aware of the tradition of saving. But what is there to save? This question is simple, but many parents and children can't afford it. Not a few children spent all money they have. It seems that this comes from their parents. Parents either when having money is spent to meet all their daily needs, so they are unable to save money. Therefore, parents invite children to "refrain" from the seduction of snacks. The attitude of restraint in the context of saving is an endeavor because the future must be sought and determined by oneself. Living simply, and not being consumptive is a rational choice of action. This must be realized in domestic life. Parenting like this can increase the opportunity for children to create plans far into the future, which of course the challenges and problems will be much heavier than today.

\section{Tips for Providing Early Financial Education}

According to Krisdayanthi (2019), saving money is financial education that can be taught to children from an early age. The following are strategies for providing financial education to children from an early age, such as, motivate the child so that the child is excited to save. Example "Son, if you are diligent in saving you will become rich people, later you can buy whatever you want". Things like this must be given to the child so that he is always motivated to save.

To be even more effective, parents and children together have different savings and encourage them too for saving. For children to be more active in saving, it is better to use existing savings media that is made attractive, such as making their savings from cardboard boxes that are made jointly by parents and children. To make it simpler, buy a place to save children such as a chicken piggy bank, a piggy bank with a superhero or cartoon that is liked by children, etc. so that when he wants to save, he will always continue to do this and become used to it.

Instilling the character of saving in children from an early age is certainly something that is highly recommended. So, that when the child becomes a teenager or an adult he can be better able to control financially and avoid wastefulness. Most parents teach their children to save from a young age. Often at school, the child is educated to set aside his allowance for savings. Until they reach adulthood, the children are then introduced to savings at the bank with all its programs. Even though many of you already have savings, you may not necessarily understand well why you are saving. Usually, you save money in banks that offer children's 
education savings programs or to buy a house. Even though there are many other reasons why someone should save money (Setiawati, 2019).

\section{CONCLUSION}

Parents must play an important role in supporting children to continue saving. So many benefits from saving should make us motivated to start training our children to set aside money. We need to learn to save from an early age so that later we can get used to and be able to prepare for the future with the savings we have. Children will not adopt the habit of saving if they often see their parents squandering money. Set an example and show what good savings habits are. Do not let children fall asleep with a comfortable life even though you earn more. Giving too many things makes children not think mature and even less appreciative of these items. Prioritize items for primary needs, such as school supplies and others.

\section{ACKNOWLEDGMENT}

Thank you to all those who helped in completing this article. This article was created so that educators and parents can teach frugal character through saving in early childhood. It is hoped that this article can be a source of literacy for educators and parents in an effort to teach saving behavior in early childhood. Finally, thanks to the obsession journal for publishing this article so that it can be read by various parties.

\section{REFERENCES}

Abdillah Mundir. (2018). Penerapan Pendidikan Financial Pada Anak Usia Sekolah. Journal of Education Al-Mudarris, 1(2), 108-120. https://doi.org/http://dx.doi.org/10.32478/almudarris.v1i2.178

Christian, M. (2018). Sadar Finansial: Pelatihan Menggunakan Informasi Digital Dalam Menggali Tujuan Menabung Pada Anak. Jurnal Pengabdian Dan Kewirausahaan, 2(1), 5160. Retrieved from http://journal.ubm.ac.id/\%0A

Hariyono, A. (2020). Literasi Keuangan Menabung Sejak Dini Dan Pendampingan Pengelolaan Keuangan Berbasis Pembukuan Sederhana Pada Bank Sampah Desa Brangkal, Kecamatan Balongpanggang, Kabupaten Gresik. DedikasiMU (Journal of Community Service), 2(1), 240. https:// doi.org/10.30587/dedikasimu.v2i1.1210

Hewi, L., \& Asnawati, L. (2020). Strategi Pendidik Anak Usia Dini Era Covid-19 dalam Menumbuhkan Kemampuan Berfikir Logis. Jurnal Obsesi : Jurnal Pendidikan Anak Usia Dini, 5(1), 158. https://doi.org/10.31004/obsesi.v5i1.530

Imelda. (2017). Pengetahuan Ibu Tentang Pemberian Stimulasi dan Perkembangan Anak Pra Sekolah (3-5 Tahun) di Banda Aceh. Idea Nursing Journal, 8(3).

Indonesia, D. K. R. (2018). Pelayanan Stimulasi Deteksi Intervensi Dini Tumbuh Kembang Anak. In Kementerian Kesehatan Republik Indonesia. https:// doi.org/10.1017/CBO9781107415324.004

Jamalul Laili, A. M. (2015). Program sentono menabung. Jurnal Inovasi Dan Keuangan, 4(1), 5457.

Krisdayanthi, A. (2019). Penerapan Financial Parenting (Gemar Menabung) Pada Anak Usia Dini. Pratama Widya: Jurnal Pendidikan Anak Usia Dini, 4(1), 1. https:// doi.org/10.25078/pw.v4i1.1063

Ludiana, N., Armin, R., \& Majapahit, U. I. (2019). Upaya Meningkatkan Semangat Menabung Pada Siswa-Siswi SDN Gumeng Melalui Metode Wa' Nakeb. Seminar Nasional Penelitian Dan Pengabdian Masyarakat - 201 9, 147-152. Retrieved from http://snp2m.unim.ac.id/index.php/snp2m/article/view/425

Marlina, N., \& Iskandar, D. (2019). Gerakan Menabung Sejak Dini di Rowosari. Jurnal Pengabdian Vokasi, 01(01), 27-32. Retrieved from https:// ejournal2.undip.ac.id/index.php/jpv/article/view/4804/2757 
Nurjanah, I., \& Efendi, J. (2018). Efektivitas Celengan untuk Melatih Pembiasaan Menabung bagi Siswa Down Syndrome. Jurnal Penelitian Pendidikan Kebutuhan Khusus, 6(2), 62-69. Retrieved from ejournal.unp.ac.id/index.php/jupekhu

Pulungan, D. R., Khairani, L., Arda, M., Koto, M., \& Kurnia, E. (2019). Memotivasi Anak Usia Dini Menabung Demi Masa Depan. Proseding Seminar Nasional Kewirausahaan, Vol. 1, pp. 296-301. https:// doi.org/https:// doi.org/10.30596/snk.v1i1.3631

Setiawati, K., \& Saputri, C. (2019). Pembinaan Edukasi Finansial Pada Anak Melalui Menabung Sejak Dini Untuk Membangun Kemandirian Keuangan. Jurnal Manajemen Pendidikan Dan Pelatihan, 3(3), 1-6. https://doi.org/https://doi.org/10.35446/diklatreview.v3i3.406

Soviah, O. F. (2019). Penyuluhan Membangun Kesadaran Menabung Sejak Dini Pada Siswa SDN 2 Lengkong Wetan Kelurahan Lengkong Wetan Tangerang Selatan Banten. In Prosiding Seminar Nasional Pengabdian Masyarakat LPPM UMJ. LPPM UMJ.

Sugiyono. (2015). Metode Penelitian Kuantitatif, Kualitatif dan R \& D. Bandung: Alfabeta.

Sulistyowati, D. (2019). Keterlibatan Ayah Dalam Pemberian Stimulasi Tumbuh Kembang Pada Anak Prasekolah. JKEP, 4(1), 1-11. https:/ / doi.org/10.32668/jkep.v4i1.276

Sumiyati. (2017). Mengenalkan Pengelolaan Keuangan Pada Anak Sejak Usia Dini. Jurnal Riset Dan Kajian Keislaman, VI(1), 29-47. Retrieved from http://journal.ipmafa.ac.id/index.php/islamicreview/article/view/121/94

Yenawati, S. (2018). Stimulasi Tumbuh Kembang Anak. Psympathic : Jurnal Ilmiah Psikologi, 3(1), 121-130. https:// doi.org/10.15575/psy.v3i1.2181 